\title{
Chronic myeloid leukemia with soft tissue infiltration : a case report
}

\author{
Gaurav Goswami, Yumkhaibam S. Devi, Laishram J. Singh
}

Regional Cancer Centre, Regional Institute of Medical Sciences, Lamphelpat, Imphal, Manipur, India

\section{ABSTRAK}

Seorang pasien laki-laki 27 tahun dengan leukemia mielositik kronik dengan pengobatan hidroksi urea yang tidak teratur, datang dengan keluhan benjolan di pangkal paha kiri disertai rasa nyeri tumpul. Pemeriksaan darah menunjukkan lekosit $125.000 / \mathrm{mm}^{3}$ dengan 13\% metamielosit, $8 \%$ mielosit, 1\% promielosit dan 3\% sel batang. Biopsi aspirasi jarum halus menunjukkan sebagian besar sel mieloblas dan sebagian kecil promielosit. Pengobatan diteruskan dengan hidroksi urea $2 \mathrm{~g} /$ hari dalam dosis terbagi, disertai allopurinol, basa dan minum yang banyak. Gejala hilang pelan-pelan setelah 2 bulan, dan benjolan hilang setelah 3,5 bulan. Hitung lekosit menjadi $38.400 / \mathrm{mm}^{3}$ dengan $1 \%$ promielosit dan mieloblas, dan 5\% batang. Pembesaran hati berkurang tapi ukuran limpa tidak mengecil. Pengobatan diteruskan dengan hidroksiurea $2 \mathrm{~g} / \mathrm{hari}$, dan gejala tidak pernah muncul lagi sampai 9 bulan terakhir.
\end{abstract}

\begin{abstract}
A 27 year old male patient with chronic myeloid leukemia under irregular hydroxyurea treatment presented with a left thigh swelling associated with a dull aching pain. Blood examination revealed a total leukocyte count [TLC] of $125,000 / \mathrm{mm}^{3}$ with $13 \%$ metamyelocytes, $8 \%$ myelocytes, $1 \%$ promyelocytes and $3 \%$ band cells. A fine needle aspiration biopsy of the swelling revealed mostly myeloblasts with occasional promyelocytes. He was maintained on tablet hydroxyurea $2 \mathrm{~g}$ given in divided daily doses along with allopurinol, systemic alkaliser and plenty of oral fluids. Gradual symptomatic relief was achieved over next 2 months with no palpable lump after 3.5 months. TLC was $38,400 / \mathrm{mm}^{3}$ with $1 \%$ promyelocytes and myeloblasts and $5 \%$ band form. There was reduction in the liver size during this period but no reduction in spleen size. He is currently being maintained on hydroxyurea $2 \mathrm{~g}$ with other supportive care and has not had any recurrence of symptoms for the last 9 months.
\end{abstract}

Keywords: chronic myeloid leukemia, extramedullary involvement, hydroxyurea, soft tissue infiltration pISSN: 0853-1773 • eISSN: 2252-8083 • http://dx.doi.org/10.13181/mji.v24i1.1083 • Med J Indones. 2015;24:50-4 - Received 13 Jan. $2015 \bullet$ Accepted 02 Mar. 2015

Correspondence author: Gaurav Goswami, dr.ggoswamicmc@gmail.com

Copyright @ 2015 Authors. This is an open access article distributed under the terms of the Creative Commons Attribution-NonCommercialShareAlike 4.0 International License (http://creativecommons.org/licenses/by-nc-sa/4.0/), which permits unrestricted non-commercial use, distribution, and reproduction in any medium, provided the original author and source are properly cited. 
Chronic myeloid leukemia (CML) is a hematopoietic disorder characterised by excessive numbers of myeloid lineage cells that are fully mature. It's incidence increases with age and has a male predominance. ${ }^{1}$ The only environmental factor implicated in the etiology of CML is ionizing radiation. It is characterized by myeloid hyperplasia of the bone marrow, extramedullary hematopoiesis, expansion of the total body granulocyte pool, elevation of the leukocyte count and a specific cytogenetic marker, the Philadelphia $\left(\mathrm{Ph}^{+}\right)$chromosome. Approximately $5 \%$ to $10 \%$ of patients with otherwise typical CML do not manifest the $\mathrm{Ph}^{+}$chromosome. ${ }^{2}$

The typical presentation is with a history of increasing fatigue, lassitude, weight loss, night sweats and splenomegaly. Less frequently chloroma, petechiae and bruising may be present. ${ }^{1}$ The course of the disease has been typically divided into a chronic phase, an accelerated phase and a blastic phase or blast crisis. Most patients present with the chronic indolent or stable phase. ${ }^{3}$

Single-agent chemotherapy with busulfan or hydroxyurea had traditionally been the standard approach to the chronic phase of CML. The goal is to achieve symptomatic relief by lowering the white blood cell count and by reducing liver and

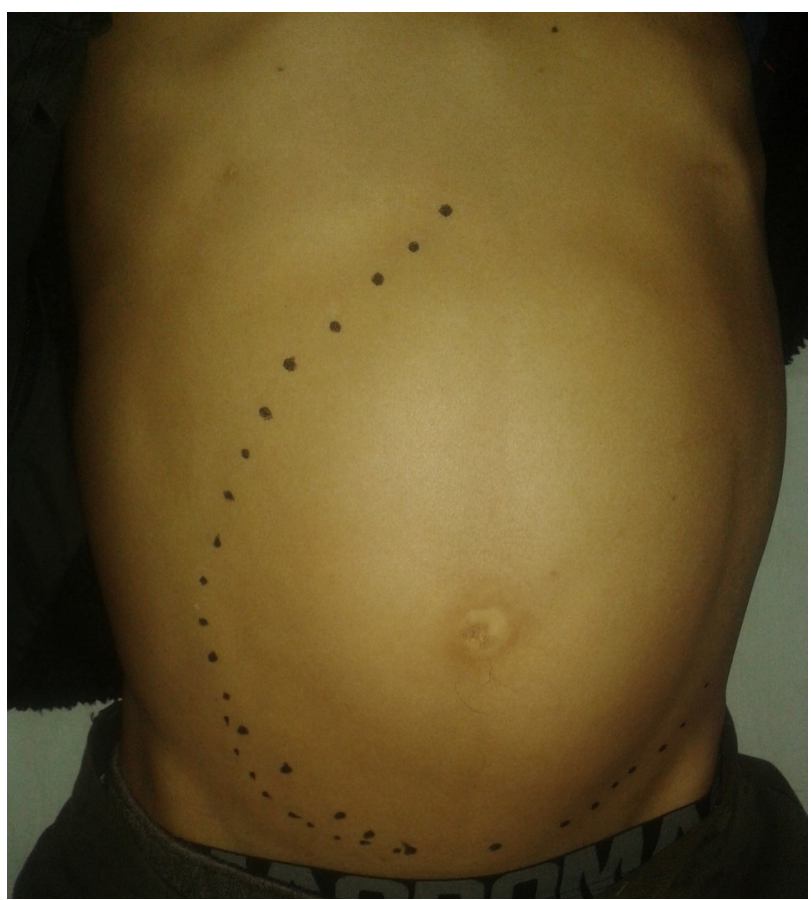

Figure 1. Huge splenomegaly in the patient at the time of presentation spleen size. ${ }^{2}$ But with the advent of the hugely effective imatinib mesylate and other tyrosine kinase inhibitors, other therapeutic agents have taken a backseat.

\section{CASE ILLUSTRATION}

A 27 year old male presented with a swelling of the left lower thigh for 20 days, associated with dull aching pain. He was a known case of chronic myeloid leukemia in chronic phase on hydroxyurea. At the time of initial presentation there was mild splenomegaly with no hepatomegaly but due to poor drug compliance, he had gradually increasing splenomegaly and hepatomegaly. Physical examination revealed moderate pallor with no sign of petechiae, bruising or sternal tenderness. On abdominal examination, spleen was found to be enlarged measuring $28 \mathrm{~cm}$ along the splenic axis. Liver was palpable about $3 \mathrm{~cm}$ below the costal swelling on the lateral aspect measuring $17 \times 12 \mathrm{~cm}$ which was mildly tender, diffuse and having restricted mobility. There was no local rise of temperature or skin changes.

Peripheral blood examination revealed a haemoglobin level of $8.4 \mathrm{~g} \%$, total leukocyte count of $125,000 / \mathrm{mm}^{3}$ with $56 \%$ neutrophils, $5 \%$ basophils, $13 \%$ metamyelocytes, $8 \%$ myelocytes, $1 \%$ promyelocytes and $3 \%$ band cells. Platelet count stood at $303,000 / \mathrm{mm}^{3}$. Liver enzymes were not raised but there was mild hypoproteinemia

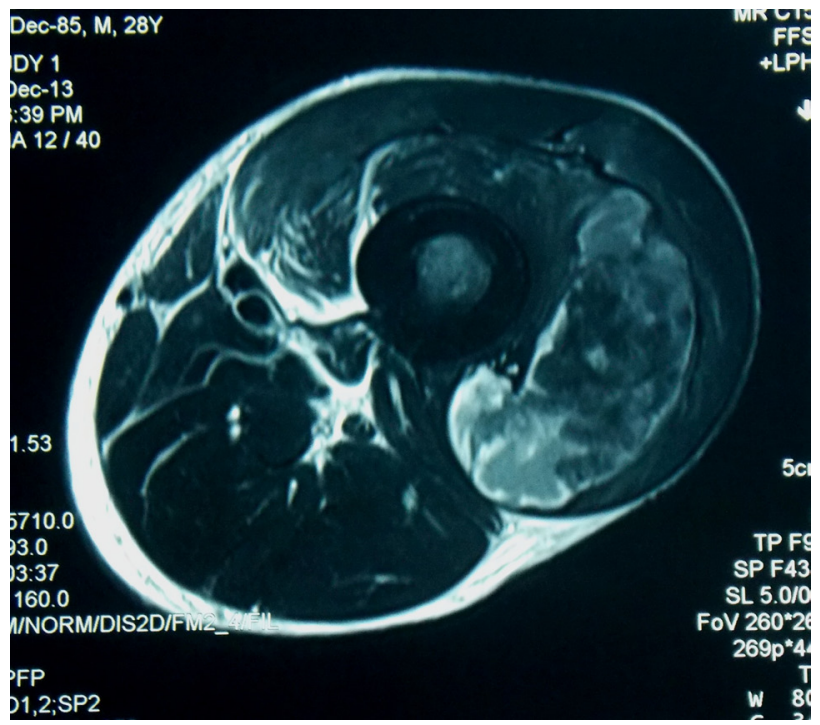

Figure 2. MRI cross-sectional imaging of the lobulated mass on the left thigh 
$(6.2 \mathrm{~g} / \mathrm{dL})$ due to hypoalbuminemia $(3.1 \mathrm{~g} / \mathrm{dL})$. Renal function test showed BUN value of $12 \mathrm{mg} /$ $\mathrm{dL}$ and creatinine at $0.7 \mathrm{mg} / \mathrm{dL}$. USG of the left thigh showed an intramuscular vascular lesion of mixed echogenicity centered in the vastus lateralis. MRI revealed cortical irregularity of the lower end of shaft of left femur suggestive of cortical erosion and marginal sclerosis. A $14 \times 14 \mathrm{~cm}$ lobulated well defined fusiform mass was noted in the lateral aspect of the mid and lower thigh in the sub-muscular plane infiltrating the muscles of lateral compartment. Mild knee joint effusion was also noted. Fine needle aspiration biopsy (FNAB) revealed an infiltration of the muscle by large cells mostly myeloblasts and occasional promyelocytes.

The patient was maintained on tablet hydroxyurea $2 \mathrm{~g}$ per day in daily divided doses, the dose being reviewed every 4 weeks. Also

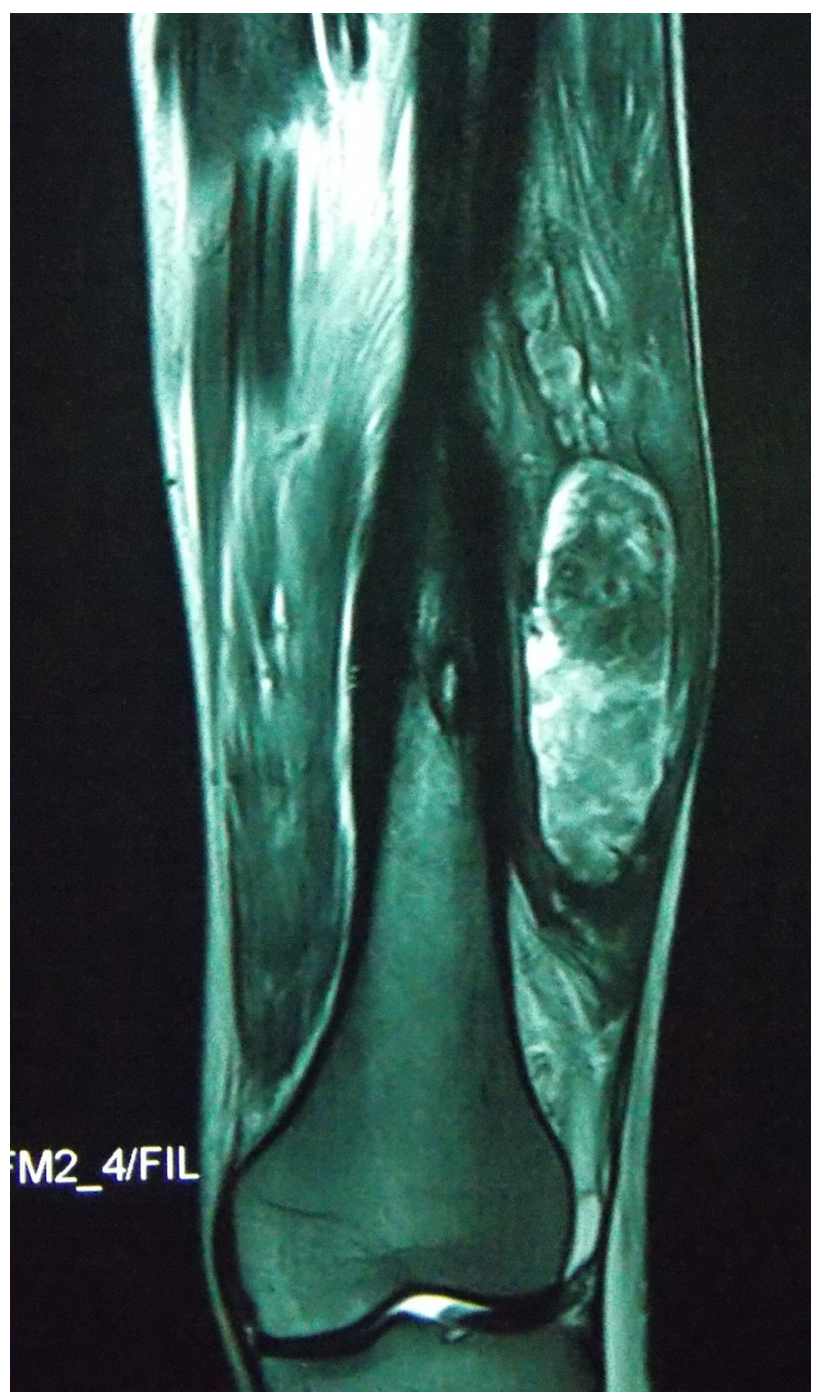

Figure 3. MRI showing a fusiform sub-muscular mass infiltration of chronic myeloid leukemia in the left thigh allopurinol $300 \mathrm{mg}$ was prescribed per orally daily and he was advised to take 2-3 litres of oral fluids along with a systemic alkaliser. Packed cell transfusions were arranged and oral analgesics were given on S.O.S basis. He was kept on a weekly follow up.

Symptomatic relief was obtained along with gradual reduction in size of the soft tissue swelling. The swelling was reduced to half at the end of 2 months and was no longer clinically palpable at the end of 3.5 months. Peripheral blood examination showed improved haemoglobin of $11.4 \mathrm{~g} \%$, a total leukocyte count of $38,400 / \mathrm{mm}^{3}$ with $1 \%$ of both promyelocytes and myeloblasts, $5 \%$ band forms and a platelet count of $307,000 / \mathrm{mm}^{3}$ at the end of two months. After 3.5 months investigations showed a haemoglobin of $8.5 \mathrm{~g} \%$, total leukocyte count of $78,200 / \mathrm{mm}^{3}, 5 \%$ myeloblasts, $7 \%$ promyelocytes, $3 \%$ myelocytes and $12 \%$ band forms with a platelet count of $286,000 / \mathrm{mm}^{3}$. However the splenomegaly did not respond to an appreciable extent.

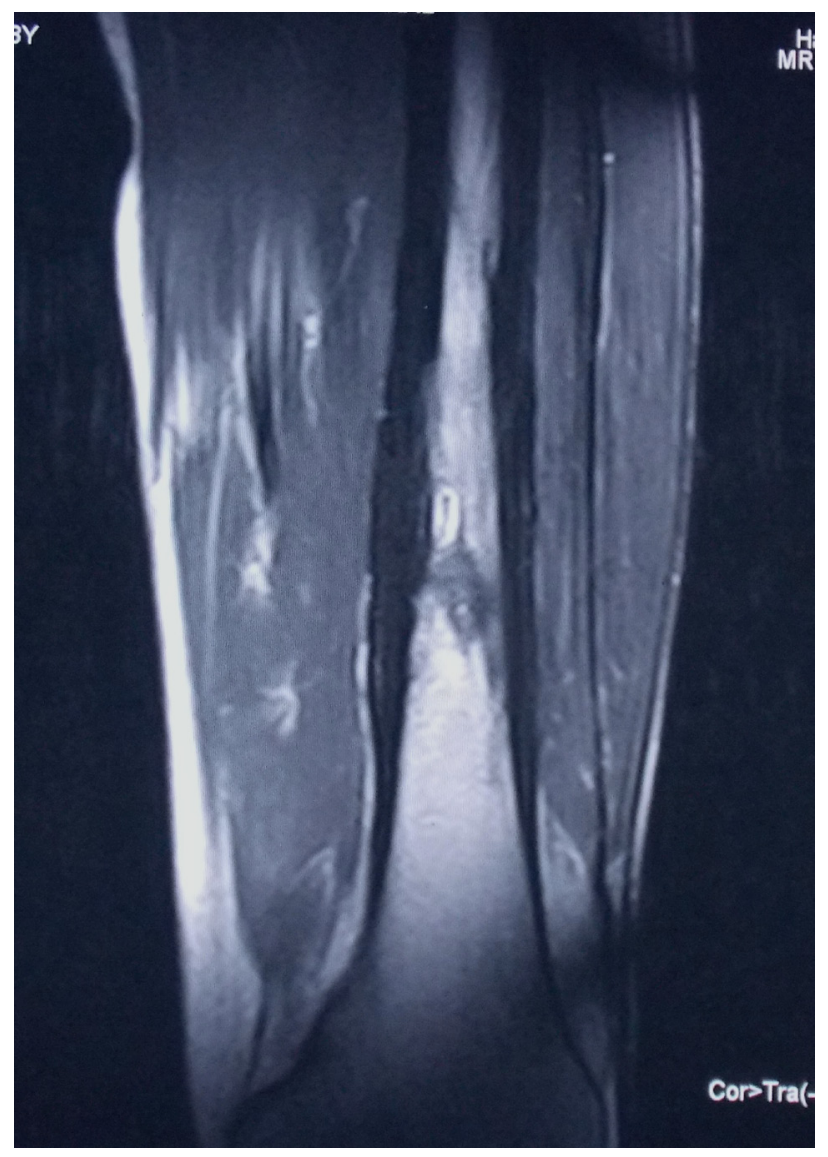

Figure 4. Post-treatment MRI of the thigh showing only sclerosis of the bone with no residual mass 
The patient is currently being maintained on hydroxyurea $2 \mathrm{~g}$ p.o and with other supportive care and blood product transfusions. His last haematological examination showed haemoglobin of $9.0 \mathrm{~g} \%$, total leukocyte count of $55,000 / \mathrm{mm}^{3}$ with $2 \%$ myeloblasts, $1 \%$ promyelocytes, $10 \%$ myelocytes, $4 \%$ band forms and a platelet count of $260,000 / \mathrm{mm}^{3}$. There has been no recurrence of any other soft tissue swelling in any other part of the body at the end of nine months.

\section{DISCUSSION}

CML is a disorder of the pleuripotent haematopoietic stem cells characterised by excessive number of cells of the erythroid, myeloid and megakaryocytic lineages which is almost always due to an acquired genetic defectreciprocal translocation involving chromosomes 9 and 22. Though it is seen in almost all age groups, its incidence increases with each decade of life making it a disease of adults. ${ }^{3}$

Extra-haematopoietic involvement is seen in conditions such as CML, MDS and AML. ${ }^{4}$ It is most commonly seen in AML when it is referred to as chloromas because of their typical green colour under the microscope owing to the enzyme myeloperoxidase. ${ }^{5}$ CML, which has sequential progression from the indolent chronic phase to the accelerated phase and finally to the blast crisis, does not usually demonstrate extramedullary infiltration (EMI) in the form of granulocytic sarcomas. Most frequently, these tumours present later in the natural history of the CML as the disease progresses. A granulocytic sarcoma that develops with chronic phase CML confers a worse prognosis with a higher risk of rapid blastic marrow transformation. ${ }^{6}$

Extramedullary infiltration with myeloid cells in CML is an uncommon presentation that may precede or occur concurrently with acute or chronic myeloid leukemia. However in our reported case, there was evidence of extramedullary involvement during the stable chronic phase with the disease never going into the accelerated phase.

The commonest sites involved with extramedullary disease are lymph nodes $110-61 \%$ of cases), followed by bone (around 33-37\%) and soft tissues (30\%). EMI in CML has been reported in body cavities, including pleura and peritoneum. Median survival is approximately 22 months, with worse outcomes more common in elderly patients. ${ }^{7}$ However in the reported case there was infiltration of a group of leg muscles which is quite an unusual presentation. At no point did the patient show any sign of infiltration of the usual sites. He did not have any history of trauma to the leg. Also, as because EMI has usually shown to be a milestone in the progression of the disease, the fact that the case under study did not show any haematological sign of rapid progression of the disease was quite unexpected.

A low-dose radiation regimen of 24 Gy in 12 fractions using conventional treatment can be applied to the majority of patients with excellent disease control and minimal morbidity. ${ }^{8}$ But the case reported did not need any such additional treatment modality. Gradual and definite resolution of the soft tissue swelling was observed over the course of time. There has been a reported case regarding EMI in CML presenting as a tumour like lesion at the end of the femur which thought to be a bone tumour retrospectively proved to be a manifestation of CML. ${ }^{9}$ Also case of compartment syndrome involving the thigh and buttocks in the paediatric age group associated with a myeloid malignancy CML has been reported which required emergency treatment. ${ }^{10}$ But such a case of EMI in CML which responded very well without involvement of any other treatment modality is quite uncommon.

In conclusion, extra-medullary manifestations of myeloid leukemias in general are poor prognostic indicators but improved outcome can be associated with it if timely intervention with appropriate therapy is done. Granulocytic sarcomas or chloromas are radiosensitive and radiotherapy may be added with chemotherapy. This case was important in that not only there was no downhill course during the extramedullary phase but also no drastic intervention was required for relief of symptoms. Extramedullary manifestations may remain a treatable condition with better outcome of cases with an early intervention.

\section{Acknowledgment}

Dr. Farooq Shafi, Department of Radiodiagnosis, RIMS, Imphal, India. 


\section{Conflict of interest}

The authors affirm no conflict of interest in this study.

\section{REFERENCES}

1. Barrett JA, Yong ASM. Chronic myelogenous leukemia. In: Rodgers GP, Young NS editors. Bethesda handbook of clinical hematology. 2nd edition. Philadelphia: Wolters Kluwer/Lippincott Williams and Wilkins; 2009. p. 160-73.

2. Altman AJ. Chronic Leukemias of childhood. In: Pizzo PA, Poplack DG, editors. Principles \& practice of pediatric oncology. 4th Edition. Lippincott Williams \& Wilkins; 2006. p. 591-614.

3. Brian DJ, Lee JS. Chronic myelogeous leukemia. In: Devita VT, Laurence TS, Rosenberg SA, editors. Cancer principles and practice of oncology. Philadelphia: Wolters Kluwer/ Lippincott Williams and Wilkins; 2010. p. 1962-72.

4. Campidelli C, Agostinelli C, Stitson R, Pileri SA. Myeloid sarcoma: extramedullary manifestation of myeloid disorders. Am J Clin Pathol. 2009;132(3):426-37.
5. Ferri E, Minotto C, Ianiello F, Cavaleri S, Armato E, Capuzzo P. Maxillo-ethmoidal chloroma in acute myeloid leukaemia: case report. Acta Otorhinolaryngol Ital. 2005;25(3):195-9.

6. Mahendra P, Ager S, Bedlow AJ, Bloxham DM, Green AR, Marcus RE. Two unusual neurological presentations of granulocytic sarcoma in Philadelphia positive chronic myeloid leukaemia. Leuk Lymphoma. 1994;15(34):351-5.

7. Imrie K, Kovacs MJ, Selby D, Lipton J, Patterson BJ, Pantalony D, et al. Isolated chloroma: the effect of early antileukemic therapy. Ann Intern Med. 1995;123(5):351-3.

8. Bakst R, Wolden S, Yahalom J. Radiation therapy for chloroma (granulocytic sarcoma). Int J Radiat Oncol Biol Phys. 2012;82(5):1816-22.

9. Longo DL, Whang-Peng J, Jaffe E, Triche TJ, Young RC. Myeloproliferative syndromes: a unique presentation of chronic myelogenous leukemia (CML) as a primary tumor of bone. Blood. 1978;52(4):793-801.

10. Lee DK, Jeong WK, Lee DH, Lee SH. Multiple compartment syndrome in a pediatric patient with CML. J Pediatr Orthop. 2011;31(8):889-92. 